\title{
A REIMAGINED RESPONSE TO DRUG OFFENSES IN THE WESTERN WORLD
}

\section{RYAN KINGHORN}

\section{LS 403 - SOCIO-LEGAL RESPONSES TO CRIME}

The "War on Drugs" is the common expression used when explaining the prevailing response to drug offenses in Western society. From the mid-1900s to present-day, a tough on crime approach has been adopted as the primary response for dealing with non-violent illegal drug offenses. The United States initiated this war and has been the dominant actor in pursuing, advancing, and influencing policy toward the criminalization of various substances used around the world. As with most aspects of the United States' economic and political culture, the country has had a significant effect on global drug policies, responses, and enforcement, especially in other western neoliberal societies like Canada and the UK. The United States has led the international movement for "tough on crime" drug policies, fuelled by the legacy of colonialism and in the interests of capitalist globalization (Reynolds, 2008). Recent drug abuse discourse has made it quite apparent that these traditional methods of dealing with the issues surrounding drugs has been rapidly feeding an increasingly oppressive, corrupt, and unproductive neo-liberal criminal justice system.

This paper will discuss the formation of the war on drugs, what has become of the originally "good intentioned" response, and identify the sources of this corrupt system. In examining the controlling, oppressive, and racialized legacy of colonialism, this paper will demonstrate that the tough on crime structure, regardless of its original intention, has evolved in the interest of a capitalist society constantly seeking tools for sustaining systematic control and inequality. In failing to achieve the goal of eradicating drug production, use, and addiction, the state has successfully achieved its consistent subconscious objective of racialization, control and power (Cummings, 2012). To recognize the racialization of drug abuse in the western world, this essay uses critical race theory as a mechanism of explanation and 
connection to the war on drugs. The concluding section of the paper will describe and analyze a reimagined response to the war on drugs, one that responds to abuse socially and medically rather than criminally. By using the case of Portugal's $20^{\text {th }}$ century drug reform, it will become clear that many countries, including Canada and the United States, have the moral responsibility to end this destructive war. With an increasing number of non-violent populations in prisons, lobbying toward prison privatization and proliferation (Cummings, 2012), continued politicization of "tough on crime" philosophies, and evolving systematic inequality, this topic is more important than ever in North America and needs to be addressed promptly. As the United States have taken the war on drugs to a level that is arguably irreparable, Canada, however, still has the opportunity to solve this issue by decriminalizing many of these banned substances in order to aid some of the underlying social problems surrounding drug abuse.

\section{The War on Drugs}

In considering these tough on crime responses to social and legal issues, it is not the responses to crimes such as murder, rape, assault, and robbery that most people are questioning, but the non-violent offenses, most of which are drug-related. With the majority of violent crimes decreasing in Western countries over the last few decades, it is fascinating to recognize the state's capacity to transform policies in order to continue nourishing capitalism and authority through punitive systems. The "prison industrial complex", a phrase discussed frequently in drug crime discourse, is the proliferation of punitive institutions due to their ability to increase profits for corporations and wealthy elites (Cummings, 2012). The war on drugs has normalized and legitimized the mass incarceration of citizens. This social atrocity is clearly exhibited in the most basic of crime statistics, with the most obvious one being the fact that the United States having roughly $5 \%$ of the world's population, but almost $25 \%$ of the world's prisoners (Cummings, 2012). With an astonishing proportion of prisoners in North American prison cells because of non-violent drug offenses, it is clear that the war on drugs is driving a very lucrative business. One of the major contributions to this corrupt system has been the implementation of private prisons, something that is predominately an American issue, but has gained attention throughout Canada in recent years. Prison 
privatization is one of the most disturbing aspects of the prison-industrial complex, as it directly contributes to an asymmetrical capitalist system (Reynolds, 2008). The privatized prison effort is one that boosts industries and generates profit via the war on drugs, combining private economic spheres with public issues.

\section{The Economization of Non-Economical Spheres}

One of the major tragedies of neoliberal drug response policies has been its capacity to be manipulated by capitalist interests. As described by Wendy Browns in her book, Undoing the Demos: Neoliberalism's Stealth Revolution, the forces of neoliberalism have economized non-economical spheres of society (Brown, 2015). The criminal justice system in Western countries has initiated an interweaving of private business and government interests in connection with incarcerating citizens (Cummings, 2012). Violent crime rates have steadily decreased over the past several decades, yet incarceration rates have rapidly increased due the benefits it brings to corporations, enterprises, investors and wealthy elites looking to extract enormous profits from business ventures, regardless of ethically responsible considerations. Corporations and investors are engaged in building, equipping and operating prisons as well as employing prisoners for cheap work, similar to third world labor (Cummings, 2012). Neoliberalism has effectively converted the political character, meaning, and operation of democratic elements into economic ones controlled by private entities (Brown, 2015). Our legal system, founded on the core values of justice, the rule of law, and responsible government has become a system controlled by those with ulterior intentions. The recent evolution of the criminal justice system is examined in both David Garland and Loic Wacquant's articles commenting on the rapid shifts in crime responses in recent years. Similar to Brown's claim, Wacquant views the expansion of the penal sector through state-constructed legitimations "an essential element of its new anatomy in the age of economic neo-Darwinism" (Wacquant, 2008). Furthermore, Garland believes that these evolving practices in policing, prosecution, sentencing and penal sanctioning are in pursuit of new neoliberal objectives, which embody an economically focused interest (Garland, 2001). In addition to the subconscious objective of freeing up capitalist markets through crime policy and privatization, the war on drugs has also remained consistent to the racialized legacy of the Western colonial 
state.

\section{Critical Race Theory, The War on Drugs, and the Legacy of Colonialism}

Systematic racism is deeply rooted in the war on drugs, pursuing the state's historically racist and oppressive character. Much of what can be understood in the analysis of drug policy and racism is through critical race theory. Critical race theory is the critique of Western society and culture regarding the intersectionality between race, law and power (Gomez, 2004). Critical race theory focuses on racial ideologies, inequalities and identity, all which have been influenced by the legacy of colonialism. In a Western society dominated by American neoliberalism, the legal system does not exist apart from race, and race is deeply rooted in the law (Gomez, 2014). Racialization is a product of society and as stated by Gomez, "racial classifications are historically contingent, the product of political contestation... and are dynamic rather than fixed or essential" (Gomez 2014, p. 457). Racial classifications and policies evolving from the colonial era have indeed changed, but are still deeply engrained in the subconscious of both the legal system as well as its participants. The legal system is grounded in ideologies, and like most ideologies, they evolve over time in order to serve elitist power relations. Drug policies have been framed as being formally neutral, just, and necessary, but it is important to understand how these ideological changes are continuing to assisting social inequalities set in place to sustain the social hierarchies (Ewick 2004, 84). As Patricia Ewick explains in her piece, Consciousness and Ideology, the state is able to develop in its citizens a "false consciousness" through various formal strategies within the legal system that block the greater population from recognizing the system for how it really is (Ewick, 2004). Based on this argument, it is understood that just because the laws have changed to appear less racialized and more equal, does not mean that our legal system has lost its racist nature. This systematic phenomenon is clearly exhibited in the neoliberal war on drugs.

\section{The War on Drugs and Racialized Communities}


The primary point of concern with the war on drugs has been its unproductive disservice to democratic societies. The war on drugs has failed to solve drug related issues and has torn communities apart along the way. As noted previously, the war on drugs is greatly racialized and lurks on marginalized members of society. As discussed by Mumia Abu-Jamal and Johanna Fernández in their controversial article about prison abolition, neoliberal governments responded to the $20^{\text {th }}$ century civil rights movement with a frenzied reaction to equal rights. With minority rights granted and equality progressed, the ruling class lost a great deal of power and control. With this loss of power, the state turned to incarceration to gain back their dominant colonial position. It was at that moment the state recognized the potential for drug criminalization to aid their crusade against the marginalized. Drugs were (and still are) very familiar to lowincome and minority communities. Moreover, these communities have high vulnerability and little influence on how their country's criminal justice system is to be operated. In 1971, United States President Richard Nixon named drug abuse "public enemy number one", and so began the domino effect of drug policy after drug policy, all trumping the other with tough on crime policies (Cummings, 2012).

The rationale of the war on drugs has recklessly assumed that there is a direct correlation between drug addiction and crime. States around the world soon followed the United States' model and harshly criminalized drug abuse. This led to a rapid change in criminal justice systems and led to a hyperincarceration of marginalized populations (Abu-Jamal \& Fernández, 2014). The $20^{\text {th }}$ century war on drugs became primarily a way to incarcerate non-violent drug offenders from disadvantaged minority populations. Irregular law enforcement, military-style responses, and vicious stereotypes quickly evolved and became systematic norms, triggering a wide acceptance of increased incarceration rates, particularly in African-American and Latino populations (Cummings, 2012).

As of 2013, there were almost half-a-million Americans in prison for drug offenses (Odeh, 2013). Of this population, roughly $65 \%$ were of African-American or Latino decent (Cummings, 2012). Furthermore, the war on drugs has had a ruthless effect on female imprisonment. Forty thousand American 
female prisoners were incarcerated for drug-related offences in 1980, and by 2003 that number increased to over four hundred thousand (Mauer, 2003). As claimed by Marylee Reynolds, the war on drugs directly triggered the $20^{\text {th }}$ century explosion of female imprisonment in neoliberal societies (Reynolds, 2008). In the year 1980, roughly $4 \%$ of all American prisoners were female, and by 2006 the war on drugs had helped this number grow to over 7\% (Reynolds, 2008). Consistent with male prisoner statistics, women of colour became disproportionally overrepresented in drug crimes (Reynolds, 2008). As some of these statistics are over a decade old, it can be assumed that these numbers are just as accurate today, as there has been little done to tackle the inequalities and racialization grounded in the war on drugs.

The racialization of disadvantaged minorities through the war on drugs has had a negative effect on individuals, families, and entire communities. Since the late $20^{\text {th }}$ century, racialized communities struck with poverty and violence have been further brutalized by the war on drugs. The response to drug crimes has led to mass incarceration, structural poverty, systematic asymmetry, economic burdens on communities, and a lack of familial structure for hundreds of thousands of people (Cummings, 2012). Many people assume that the majority of injustices surrounding the war on drugs are mainly American issues, and while the situation has become quite extreme in the United States, it is still very relevant in Canadian society. For example, in 2011, black prisoners in Canada "accounted for 9\% of the federal prison population" even though the black population made up only $2.5 \%$ of the overall Canadian populace (Wortley \& OwusuBempah, 2011). Reynolds accurately describes the United States' ability to expand their tough on crime drug ideologies globally through their international hegemonic status and authority (Reynolds, 2008). The global spread of the war on drugs has influenced both Canadian drug policies as well as the racialized discrimination involved in the war. Akwatu Khenti notes that the war on drugs has intensified the "systemic historical, political, social and economic process whereby black men who have long been stereotyped as criminals are now targeted as the enemy... regardless of the involvement of other racial communities" (Khenti, 2013). Racial profiling has become the reality for black males in Canada, due to the war on drugs' social construct of the black male ganger and drug dealer (Cummings, 2012). Thousands of social minorities 
are discriminated against and abused daily in the United States, Canada, and in other Western societies due to the negative connotations that have evolved as a result of this war and the state's colonial nature.

\section{Drug Abuse in the $21^{\text {st }}$ Century}

Like alcohol prohibition in the early 1900s, the prohibition of drugs has been completely ineffective in its objectives. By treating drug abuse as a criminal matter, the war on drugs has completely missed the point on how to deal with such an issue. The United Nations has estimated that the global drug trade is worth more than $\$ 320$ billion, with over 200 million people using "illegal" drugs around the world (United Nations, 2012). It is not a debate on whether our strict criminalization of drugs and tough punishment of drug offenders has even slightly eradicated the drug industry. Making drugs illegal is not stopping the production, use, and addiction to drugs in Canada, the United States, or around the world. As a matter of fact, the United States, with some of the harshest drug laws in the world, is also the world's leader in illegal drug use (Warner, 2008). The debate on drug laws is not one that is trying to undermine the harmful social, mental, and physical effects that drugs can have on its consumers. It is undeniable that many drugs have serious and even detrimental effects on their consumers. The goals of the war on drugs and the goals of drug decriminalization are the same: protecting our kids, educating society, protecting public safety, repairing systematic inequalities, and preventing and treating drug abuse and addiction (Branson, 2012). In addition to the irreparable social damages the war on drugs has done, this response to drugs has evidently driven the industry into a dark and underground trade, led by cartels, gangs, and other dangerous individuals and groups. These are not the people we want to have access to $\$ 300+$ billion. If any of this is going to change, society needs to ignore the capitalist engine driving the oppressive legal subconscious and understand that illegal drugs are not a criminal issue, but a social and medical issue that can be resolved through more rational methods and responses.

\section{A Reimagined Response to Drug Offenses}


Although some scholars make persuasive claims in support of absolute prison abolishment, realistically it is not a rational or feasible response to most crimes. The prison system has many legitimate and just qualities that benefit the greater good of society. That being said, non-violent drug offenders do not belong in the same place as violent or dangerous offenders. What can be taken from Mumia Abu-Jamal and Johanna Fernández's ideas and applied to reimagining the war on drugs however is their call for community revitalization programs and dynamic rehabilitation becoming mainstream (Mumia Abu-Jamal \& Johanna Fernández, 2014). The war on drugs has devastated far too many lives in the United States, Canada, and around the world. Social priorities need to shift from economic ones motivated by wealth, to social ones motivated by fairness. As examined by many academics and researchers, it is going to be a nearimpossible task to successfully tackle the systematic inequalities induced by neoliberalism (Brown, 2015). Moreover, there are many additional social inequalities progressing through neoliberalism that need to be dealt with above and beyond the war on drugs. The war on drugs is just one of these issues, but it is in fact an issue that appears to have a more realistic chance at being reimagined and revolutionized than other systematic injustices.

The reimagined alternative to the dominant legal response to the war on drugs is not a simple one. The key element of the drug revolution is the social reconstruction of illegal drug abuse. A systematic and social reframing of drug abuse from a criminal problem to a social and/or medical problem is necessary. Instead of treating drug users and addicts as moral delinquents, the responses need to be developed with a better understanding of the social and medical roots related to drug abuse. Although Canada has taken many steps to reform drug responses, as examined in The Benevolent Watch: Therapeutic Surveillance in Drug Treatment Court (Moore, 2011), there are still many significant steps the nation could be taking to end the damaging war on drugs. Fortunately, Canada can learn by example by adopting some of the various alternatives that have been implemented by other Western countries, recognizing the unproductive nature of the war as well as its damaging social effects. 
Portugal is the prime example of how neoliberal countries ought to deal with the issue of drug abuse. In 2001, Portugal adopted laws and procedures that almost completely eliminate jail time for most drug offenses (Drug Policy Alliance, 2015). While completely legalizing some drugs violates United Nations policies, Portugal has decided to simply decriminalize most drugs. Non-violent individuals caught with a relatively small amount of illegal drugs such as marijuana, cocaine, or heroin receive a misdemeanour charge similar to a parking ticket (Hollersen, 2013). As it is evident in countries like Canada and the United States that the criminalization of drugs is doing a disservice to society, the same was identified in Portugal. At the start of the new millennium, Portugal decided to "pave a new path" by decriminalizing drugs of all kinds in order to improve national public safety and health (Hollersen, 2013). The Portuguese government consulted crime and drug statistics and accepted the fact that that the issue of drug abuse was to be framed as a public health one, not a criminal one. Portugal now deems drug abusers as being sick, rather than delinquent, and has thus stopped treating them as criminals. That being said, drugs are still illegal in Portugal. When an individual is caught with a drug possession lower than the legal limit, they are required to attend the "warning commission on drug addiction" where a panel consisting of three members (usually a lawyer or a judge, a doctor, and a psychologist) have three options: recommend treatment, levy a small fine, or do nothing. Counseling is in fact the most common approach (Cummings, 2012). On the other hand, when an individual is caught with a drug possession higher than the legal limit, they are presumed to be a drug dealer and are summoned to criminal court to be dealt with in accordance to mainstream drug charges. (Hollersen, 2013).

As stated by João Goulão, the Portuguese drug czar and key influencer of these new policies, "our most important duty is to invite people to participate in rehab"..."Decriminalization is pointless without being accompanied by prevention programs, drug clinics and social work conducted directly on the streets" (Hollersen, 2013). That is exactly the main objective in ending the war on drugs. Having a healthier, more equal, and less mistreated population should be the highest priority of a truly responsible government. As 
it is noted below, refusing to surrender to the forces of capitalism and abolishing the war on drugs can have significant benefits that clearly outweigh the costs.

In 2015, almost a decade and a half after the Portuguese drug reform, the Drug Policy Alliance, a non-profit organization dedicated to ending the global war on drugs, developed a report on the effects such policy changes have had on Portuguese society. First, their research found that there is no major increase in the use of drugs among the population. This should not come as a surprise due to the fact that drugs are as accessible as they have ever been around the world and people will continue to do drugs, regardless of whether they are legal. Secondly, the researchers found the rate of Portuguese minors abusing drugs to be decreasing, which is a very positive social change. Third, there has been a substantial decrease in the amount of citizens arrested and incarcerated for drugs. This is one of the most problematic elements of the reform for North American countries, as it directly competes with the neoliberal prison-industrial complex mentioned earlier. Unfortunately, the reality in countries such as Canada and the United States is that politicians are highly influenced by corporate profiteers, the ones whom are profiting greatly from the war on drugs and mass incarceration (Cummings, 2012). Because of this capitalist corruption, it will be much harder in countries like these to mobilize, lobby, and influence effective drug reform. Nevertheless, other remarkable findings from the Portugal Drug Policy Alliance study are that there has been less drug-induced deaths, more citizens seeking rehabilitation, lower rates of new HIV infections, and a significant amount of money saved by the state. The decriminalization of drugs has the ability to transfer the tax dollars from law enforcement and courtrooms to rehabilitation and education.

These are all very critical social enhancements that could easily be mirrored in a country such as Canada. With more liberal ideologies, welfare objectives, and much less corporate influence than the neighboring U.S., Canada could easily be the next western society to end the war on drugs. Despite the forces of neoliberalism, there is still hope in both Canada and the United States. In Canada, newly elected Prime Minster Justin Trudeau has been very open about his views on drug decriminalization and increasing social assistances programs such as rehabilitation (Glenny, 2015). On the American side, Democratic 
candidate Bernie Sanders has been gaining a great deal of popularity and publicity due to his revolutionary visions of what the United States can be by adopting socialist values. As a self-proclaimed socialist, Sanders believes that the United States needs a bold change in the criminal justice system and a productive first step would be to "start treating prisoners as human beings, not profiting from their incarceration (Bernie 2016, 2015).

The war on drugs has done a lasting disservice to western society. Fuelled by the colonial legacy of hatred and greed, this war has economized non-economical social spheres, further racialized populations, destroyed communities, and hyper-incarcerated innocent victims of a mental medical illness. With Portugal being a prime example of how a government should respect its citizens and care for their wellbeing, the war on drugs must be ended in Canada and around the world immediately. 


\section{References}

Abu-Jamal, M. \& Fernández, J. (2014). Locking Up Black Dissidents and Punishing the Poor: Roots of Mass Incarceration in the US. Socialism and Democracy, 28(3), 1-14.

"Bernie 2016". (2015, September 8). Sanders: Our Criminal Justice System is Broken, Ending Private Prisons is a Good First Step Forward. Retrieved from https://berniesanders.co $\mathrm{m} /$ press-release/ending-private-prisons/

Branson, R. (2012, December 7). War on drugs a trillion-dollar failure. Retrieved from http://www.cnn.com/2012/12/06/opinion/branson-end-war-on-drugs

Brown, W. (2015). Undoing Democracy: Neoliberalism's Remaking of State and Subject. In Undoing the Demos: Neoliberalism's Stealth Revolution. New York: Zone Books, 17-46.

Cummings, A. (2012). 'All Eyez on Me': America's War on Drugs and the Prison Industrial Complex. The Journal of Gender, Race \& Justice, 15(3), 417-448.

Drug Decriminalization in Portugal: A Health-Centered Approach. (2015). We Are the Drug Policy Alliance, 1-3.

Ewick, P. (2004) 'Consciousness and Ideology' in Blackwell Companion to Law and Society, pp. 80-92.

Garland, D. (2001). A History of the Present. In The Culture of Control: Crime and Social Order in Contemporary Society. Oxford: Oxford University Press, 1-26.

Glenny, M. (2015, November 25). Why easing marijuana laws is a good first step. Retrieved from http://www.theglobeandmail.com/globe-debate/why-easing-marijuana-laws-is-agood-first-step/article27468827/

Gomez, L. (2004) 'A Tale of Two Genres: On the Real and Ideal Links Between Law and Society and Critical Race Theory' in Blackwell Companion to Law and Society, pp. 435452.

Hollersen, W. (2013). 'This Is Working': Portugal, 12 Years after Decriminalizing Drugs. Retrieved from http://www.spiegel.de/international/europe/evaluating-drugdecriminalization-in-portugal-12-years-later-a-891060.html

Hughes, C. (2012). The Portuguese decriminalisation of illicit drug use: What the AOD field should know. Retrieved from https://dpmp.unsw.edu.au/sites/default/files/dpmp/resources /HUGHES.pdf

Khenti, A. (2014). The Canadian war on drugs: Structural violence and unequal treatment of Black Canadians. International Journal of Drug Policy, 25(2), 190-195. Retrieved from http://www.sciencedirect.com.proxy.lib.uwaterloo.ca/science/article/pii/S09553959130023 02

Mauer, M. (2003). Comparative International Rates of Incarceration: An Examination of Causes and Trends. The Sentencing Project. Washington, DC. 
Moore, D. (2011). The Benevolent Watch: Therapeutic Surveillance in Drug Treatment Court. Theoretical Criminology, 15(3), 255-268.

Odeh, R. (2013). Emerging From the Haze of America's War on Drugs and Examining Canada's New Half-Baked Laws. Fordham International Law Journal, 36(1), 198-238.

Reynolds, M. (2008). The War on Drugs, Prison Building, and Globalization: Catalysts for the Global Incarceration of Women. NWSA Journal, 20(2), 72-95.

The United Nations. (2012). Thematic Debate of the 66th session of the United Nations General Assembly on Drugs and Crime as a Threat to Development On the occasion of the UN International Day against Drug Abuse and Illicit Trafficking. Retrieved from http://www.un.org/en/ga/president/66/Issues/drugs/drugs-crime.shtml

Wacquant, L. (2008). Ordering Insecurity: Social Polarization and the Punitive Upsurge. Radical Philosophy Review, 11(1), 9-27.

Warner, J. (2008). U.S. Leads the World in Illegal Drug Use. Retrieved from http://www.cbsnews.com/news/us-leads-the-world-in-illegal-drug-use/

Wortley, S., \& Owusu-Bempah, A. (2011). The usual suspects: Police stop and search practices in Canada. Policing and Society, 21(4), 395-407. 
IIII VOLUME 1 | 2016

P a g e $\mid \mathbf{5 9}$ 
